Uşak Üniversitesi Sosyal Bilimler Dergisi

$2014,7(1), 244-263$

\title{
Okuma Yazmaya Hazırlık Çalışmalarına Yönelik Öğretmen Görüşleri
}

Özet

Sadegül AKBABA ALTUN* Özlem ŞIMŞEK ÇETIN ${ }^{* *}$

Döndü Neslihan BAY***

Çalışmanın amacı okul öncesi öğretmenlerinin okuma yazmaya hazırlık çalışmalarına ilişkin görüşlerini belirlemektir. Bu amaca ulaşabilmek için nitel araştırma yöntemlerinden görüşme yöntemi kullanılmıştır. Araştırmanın çalışma grubu Ankara il merkezinde anasınıfı ve anaokullarında görev yapan 48- 60 aylık (5 yaş) ve 61- 72 aylık (6 yaş) çocuklar ile çalışan dört öğretmenden oluşmaktadır. Araştırmada öğretmenlerin görüşleri araştırmacılar tarafından hazırlanmış yarı yapılandırılmış görüşme soruları aracılığıyla toplanmıştır. Araştırma sonucunda görüşme yapılan öğretmenlerin okuma yazmaya hazırlık çalışmaları kapsamında kavram, ses ve çizgi çalışmalarına yer verdiklerini belirttikleri görülmüştür. Kavram ve yazmaya hazırlık çalışmalarının ilköğretime hazırlıkta önemli oluğunu belirttikleri, yazı farkındalığına yönelik çalışmalarla ilgili görüş bildirmedikleri saptanmıştır. Öğretmenlerin okuma yazmaya hazırlık çalışmalarında materyal olarak, kavram kitaplarında yer alan çalışma sayfalarını daha çok tercih ettikleri tespit edilmiştir.

Anahtar Kelimeler: Okuma yazmaya hazırlık, okul öncesi eğitim, okul öncesi öğretmeni

\section{Teacher Views On Reading And Writing Preparation Studies}

\begin{abstract}
The aim of the study is to specify pre-school teachers' views on reading and writing preparation studies. In order to reach this aim, interview method, a type of qualitative research, was used. The study group of the research consists of 48-60 months old (5years) and 61-72 months old (6 years) children and 4 pre-school teachers who are bound to kindergartens

\footnotetext{
* Prof.Dr., Başkent Üniversitesi, Eğitim Fakültesi, Eğitim Bilimleri Bölümü

** Yrd.Doç.Dr., Kırıkkale Üniversitesi, Eğitim Fakültesi, İlköğretim Bölümü

*** Yrd.Doç.Dr., Eskişehir Osmangazi Üniversitesi, Eğitim Fakültesi, İlköğretim Bölümü
} 
in Ankara province center. The views of the teachers are collected via semistructured interview questions prepared by the researchers. At the end of the research, it was observed that the interviewed teachers implement concept, sound, and line exercises for the reading and writing preparation studies. It was ascertained that they found concept and writing preparation studies important for primary school; however, they stated no views about the studies related to writing awareness. It was detected that they made more use of worksheets in the concept books as a material for reading and writing preparation studies.

Key Words: Reading and writing preparation studies, preschool education preschool teacher

\section{Giriş}

Okuma ve yazmaya hazırlık becerileri çocukların ilkokula başlamadan önce doğal olarak katıldıkları bir süreçtir (Morrison, 1998). Çocuğun ilkokula ve özellikle de okumaya başlayabilmesi için gerekli olan gelişme düzeyini tamamlamış olması gerekmektedir. Bu gelişme düzeyi okumaya hazır olma kavramı ile tanımlanmaktadır. Okumaya hazırlık çocuğun okumaya başlaması için gerekli tüm bilgi ve becerilere sahip olması anlamına gelmektedir (Kılıçarslan, 1997). Okul öncesi dönemdeki çocuğun okuma yazmaya hazırlık becerilerini okuryazarlık gelişimi içinde açıklamak mümkündür. Okuryazarlık gelişimi dinleme, konuşma, okuma ve yazma becerilerinden oluşmaktadır. Okuryazarlık becerilerini oluşturan bu dört bileşen birbiri ile etkileşim içindedir, bir alandaki gelişme diğer alandaki gelişimi de etkilemektedir (Eliason ve Jenkins, 2003; Jackman, 2005; Miller, 1996). Okul öncesi dönemdeki çocukların gelişimsel olarak gösterdikleri dinleme, konuşma, okuma ve yazma becerilerinin, okul öncesi eğitim programı içinde yer alması önemlidir. Okul öncesi dönemdeki çocuğun okuma ve yazma becerilerini geliştirebilmek için eğitim programı içinde hem yazılı hem de sözel dil becerilerinin desteklenmesi gerekmektedir. Bu bağlamda, okul öncesi dönemdeki çocukların, okuma ve yazma becerileri ile ilgili olarak, sözel dil becerileri, ses farkındalığı, yazı farkındalığı, yazma alanlarında desteklenmesi önem taşımaktadır (Brennan, 2008; Cabell ve diğerleri, 2011; Dodge, Colker ve Horeman 2002; Kandır, Tezel Şahin, Dilmaç ve Yazıc1, 2010; Murphy, 2007; Pullen ve Justice, 2003; Seefeldt, 2005; Story, 2008; Vukelich, Christie ve Enz , 2008). Türkiye'de uygulanan MEB (2006) 36-72 Aylık Çocuklar İçin Okul Öncesi Eğitim Programı'nda yer alan okuma yazmaya hazırlık çalışmaları; görsel algılama çalışmaları (el- göz koordinasyonu, şekil zemin ayrımı, şekil sabitliği, mekanda konum, mekansal ilişkiler, işitsel algı çalışmaları (dinleme, konuşma, sesleri ayırt 
etme, seslerle nesneleri ya da nesnelerle sesi birleştirme), dikkat ve bellek çalışmaları, temel kavram çalışmaları, problem çözme çalışmaları, elbecerisi çalışmaları (çizme, boyama, katlama...), özbakım becerilerini geliştirme çalışmaları, güven ve bağımsız davranış geliştirme çalışmaları başlıkları altında yer almaktadır. Ancak bu çalışmaların bazılarının ilköğretime hazırlık ilgili genel çalışmalar olduğu görülmektedir. Mevcut programdaki bu durumun okul öncesi öğretmenlerinin okuma yazmaya hazırlıkla ilgili uygulamalarında karışıklığa neden olduğu düşünülmektedir. Okul öncesi öğretmenleri, çocukların bilgi düzeylerini, anlama düzeylerini gözlemleyerek, eğitime başlama noktasına karar vermelidirler (Bloch, 2000). Bu çocukların öğrenmelerine fırsat sağlamak ve uygun ortamı oluşturmak için önemli ve gereklidir. Öğretmenler rollerini, öğrenmeye rehberlik etme ve öğrenmeyi yönlendirme olarak genişletmelidirler. Okul öncesi öğretmenlerinin, çocukların okuma yazmaya hazırlık çalışmalarındaki becerilerinin gelişmesine katkı sağlayacak aktiviteleri kullanmaları gerekmektedir (Bodrova ve Leong, 1999). Türkiye'de okul öncesi öğretmenlerinin okuma yazmaya hazırlık etkinliklerine ilişkin uygulamaları, görüşleri, yeterlilik algıları, okuma yazma hazırlık çalışmalarının ilk okuma yazma sürecindeki etkisine ilişkin çeşitli çalışmalar bulunmaktadır (Bay, 2008; Deretarla Gül ve Bal, 2006; Güleç, 2008; Pehlivan, 2008; Tuğluk ve diğerleri, 2008; Yangın, 2006; Parlakyıldız ve Yıldızbaş, 2004). Bu araştırmada okul öncesi öğretmenlerinin okuma yazmaya hazırlık çalışmaları ile ilgili görüşleri MEB (2006) 36-72 Aylık Çocuklar İçin Okul Öncesi Eğitim Programı'nda yer alan okuma yazmaya hazırlık çalışmaları, MEB (2005) İlköğretim Türkçe Öğretim Programı ve Kılavuzunda yer alan öğrenme alanları ve literatürde yer alan okuryazarlık çalışmaları kapsamında değerlendirilecektir. Araştırmanın bu yönüyle önemli olduğu ve alana katkı sağlayacağı düşünülmektedir.

Araştırma Sorusu: Okul öncesi öğretmenlerin okuma yazmaya hazırlık çalışmaları ile ilgili görüşleri nelerdir?

\section{Yöntem}

$\mathrm{Bu}$ bölümde araştırmanın modeline, araştırmacının rolüne, katılımcılara, araştırmada izlenecek sürece, verilerin toplanmasına ve verilerin analizine yer verilmektedir.

\section{Araştırmanın Modeli}

Araştırma betimsel bir durum saptaması niteliğinde olup, nitel araştırma teknikleri temel alınarak desenlenmiştir. Araştırmada nitel araştırma çeşidi olan tipik durum çalışması yöntemi kullanılmıştır. Durum çalışmalarındaki amaç belirli bir duruma ilişkin sonuçlar ortaya koymaktır 
(Yıldırım ve Şimşek, 2008). Bu araştırmada durumu ortaya koyabilmek için öğretmenlerle görüşme yapılmıştır.

\section{Katılımcilar}

Araştırmada amaçlı örnekleme yöntemlerinden ölçüt örnekleme yöntemi kullanılmıştır. Ölçüt örnekleme bir dizi ölçütü karşılayan bütün durumların çalışılmasıdır (Yıldırım ve Şimşek, 2008). Çocukların ilköğretime hazır başlayabilmeleri açısından 5 (48- 60 ay) ve 6 (61- 72 ay) yaş grubunda okuma yazmaya hazırlık çalışmalarını yapılması açısından önemlidir. Araştırmada çalışmaya katılacak öğretmenlerin hem 48- 60 ay hem de 61- 72 ay aralığındaki çocuklarla çalışması ölçüt olarak belirlenmiştir. Bu nedenle anaokulunda ve anasınıfında görev yapan öğretmenler katılımcı olarak seçilmiştir. Araştırmanın katılımcıları; Milli Eğitim Bakanlığına bağlı bağımsız anaokullarında görev yapan üç, anasınıfında görev yapan bir olmak üzere toplam dört öğretmenden oluşmaktadır. Anaokulunda görev yapan öğretmenlerden ikisi 48- 60 aylık çocuklarla, biri ise 61- 72 aylık çocuklarla çalışmaktadır. Öğretmenlerin tamamı okul öncesi eğitim alanında lisans mezunudur. Anaokulunda görev yapan öğretmenlerin mesleki deneyimi 3 ve 5 yıl arasında değişirken, anasınıfında görev yapan öğretmen 10 yillık mesleki deneyime sahiptir.

\section{Verilerin Toplanması}

$\mathrm{Bu}$ araştırmanın verileri, Ocak-Mayıs 2011 tarihleri arasında öğretmenlerin uygun oldukları zamanda, kendi okullarında yapılan görüşmeler yoluyla toplanmıştır. Verilerin toplanmasında, görüşme türlerinden yarı-yapılandırılmış görüşme tekniğinden yararlanılmıştır. Araştırmacılar tarafından hazırlanan yarı-yapılandırılmış görüşme formu kullanılarak, öğretmenlerin okuma yazmaya hazırlık çalışmalarına ilişkin görüşleri belirlenmiştir. Görüşme formunun iç geçerliğini sağlamak için görüşme formu üç alan uzmanının görüşüne sunulmuştur. Uzmanların önerileri doğrultusunda forma son sekli verilmiştir. Her bir öğretmen ile bire bir görüşme yapılmıştır. Görüşmeler yaklaşık 40 dakika sürmüştür. Görüşme sonuçları görüşme formuna kaydedilmiştir. Araştırmada öğretmenlerin görüssleri yarı yapılandırılmış görüşme formundaki sorulara verdikleri cevaplarla sınırlı kalmıştır.

\section{Verilerin Analizi}

Öğretmenlerin görüşme formuna kaydedilen cevaplarından elde edilen verilerin çözümlenmesinde, betimsel analiz tekniği kullanılmıştır. Betimsel analiz tekniği ile veriler özetlenmiş ve yorumlanmıştır. Betimsel analizin amacı, ham verilerin okuyucunun anlayabileceği ve isterlerse kullanabileceği bir hale getirilmesidir. Bunun için veriler araştırma 
sorularının ortaya koyduğu temalara göre oluşturulur ve görüşmede kullanılan sorular dikkate alınarak sunulur. $\mathrm{Bu}$ analizde, görüşülen bireylerin görüşlerini çarpıcı bir biçimde yansıtmak amacıyla doğrudan alıntılara sık sık yer verilmektedir (Yıldırım ve Şimşek, 2008). Görüşmeler şu aşamalar doğrultusunda değerlendirilmiştir: Araştırmanın amacı doğrultusunda öğretmenlere sorulan sorular temalar olarak belirlenmiştir. Sorulara verilen yanıtlar bu doğrultuda incelenerek bu temalara yapılan vurgular belirlenmiş ve bu öğretmenlerin görüşleri sunulmuştur. Daha sonra öğretmenlerin yanıtları direkt alınarak tırnak içinde verilmiş ve yorumlanmıştır.

\section{Bulgular}

Bu bölümde öğretmenler ile görüşmelerden elde edilen bulgular yer almaktadır. Görüşmeler sonucunda elde edilen bulgular sorulara göre sıralanarak verilmiştir.

Okuma yazmaya hazırlık çalışmalarının uygulanma sıklığı: Öğretmenlerin hemen hemen her gün okuma yazmaya hazırlık çalışmalarına yer verdikleri görülmüştür. Ancak görüşme yapılan bir öğretmenin 5 yaş (48- 60 ay) grubundaki çocuklar için okuma yazmaya hazırlık çalışmalarının her gün yapılmasının gerekli olmadığını düşündüğü tespit edilmiştir. Buna ilişkin görüşler aşağıda verilmiştir.

"Her gün yapıyorum. Yarım günlük eğitimde okuma yazmaya hazırlı çalışmalarını yetiştiremiyordum ve 6 yaş öğretmeniydim. Şimdi ise 5 yaştayım ve tam gün eğitim veriyorum. Aslında her gün okuma yazmaya hazırlık çalışmalarını yaptırmama gerek yok ama zamanım olduğu için yaptırıyorum."

Okuma yazmaya hazırlık etkinliği kapmasında yapılan çalışmalar: 6 yaş (61- 72 ay) grubu öğretmenleri okuma yazmaya hazırlık çalışmaları kapsamında kavram, çizgi ve ses çalışmalarını yaptıklarını vurgulamışlar ve bu çalışmaları yaparken basitten karmaşığa bir yol izlediklerini belirtmişlerdir. 5 yaş (48- 60 ay) grubu öğretmenleri ise ağırlıklı olarak kavram çalışmalarına yer verdiklerini ifade etmişlerdir. Her iki yaş grubundaki öğretmenlerin okuma yazmaya hazırlık etkinlikleri içerisinde sayılar ve geometrik şekillerle ilgili çalışmalara yer verdiklerini belirttikleri görülmüştür. Bu soruya ilişkin öğretmenlerin ifadeleri aşağıda verilmiştir. 6 yaş (61- 72 ay) grubu öğretmenlerinden biri çizgi çalışmalarını kitap kullanarak yaptırdığını ve basitten karmaşığa giden bir yol izlediğini, şu cümlelerle ifade etmiştir: 
"Çizgi kitabımız var genelde onu kullanıyorum. Onun içinde noktaları tamamlama var. Sayılar noktalı şekilde tamamlama yapıyorum. Faaliyetler var. Kitaplar var noktalar tamamlamaya yönelik, onları yapıyoruz, bu tarz şeyler genelde yaptırdığım çalışmalar. Bazen serbest resim yaptırıyorum. Önce basit çalışmalar vererek sonra biraz daha zor olanlara doğru ilerliyorum. Basit derken yani, karmaşık olmayan yüzeysel, nokta nokta olan çubuklar halinde olan çizimler, sonra daha resim içinde karmaşık olan noktalar şeklinde...."

Bir başka öğretmen okumaya hazırlık çalışmasında ses çalışmaları yaptığını "Harf üretme çalışmalar yapıyoruz, hikaye okumadan önce örneğin $i$ harfi ile başlayan sözcükler bulma gibi..." ifadesiyle belirtmiştir.

Okuma yazma çalışmalarında öğretmenlerin tek bir çalışmanın yapmadıkları çizgi çalışması, ses çalışması gibi farklı etkinliklere yer verdikleri görülmektedir. Bir öğretmen ise sayı, renk gibi kavramlarla ilgili çalışmalar yaptığını ve harflerle ilgili çalışmalar yapmayı planladığını, aşağıdaki sözcüklerle ifade etmiştir.

“Sayılarla ilgili çalışmalar yapıyoruz. Önce daha çok vücutlarını tanımaya yönelik, vücut organların ya da nesneleri sayarak çalışıyoruz. Sonra havada sayılar yazarak, sonra da duvarlara kağıt yapıştırarak onların üstüne yazarak çalışıyoruz. En sonunda kitap üstünde yazıyoruz. Renklerle ilgili çalı̧ma yapıyoruz. Renk karışımları ile ilgili deney şeklinde yaptık, birinin elini sarıya birinin elini maviye boyadık. Renk karışımların görmeleri için oyun oynadık.. Harflerle ilgili çalışmak istiyorum, ama ikinci dönem..".

Başka bir öğretmen ise okuma yazmaya hazırlık kapsamında harf yazma çalışmalarını yaptırmadığını vurgulamış, bunun yerine harfi gösterme ve ses çalışması yaptığını şöyle ifade etmiştir:

"Çoğu zaten ismini yazmayı biliyor. Genel olarak adındaki baş harfleri tanıyorlar. Onun dışında birkaç harfi tanıyan çocuk da var. Annemin babamın adını yazabiliyorum diyen çocuklar var. Ama ben sadece sembol olarak göstermeyi düşünüyorum. Çünkü el yazısı normal yazıdan farkl, biz kağıtların üstüne filan normal yazıyla yazdığımız için düz yazıyı öğreniyorlar, o yüzden sadece sembol olarak ya da sadece ses olarak öğretmeye çalıyorum. O harfle başlayan nesneler ya da hayvanlar gibi. Adını söylediğinde fark etmesini sağlayacak ya da o hayvanı seslerle ilgili tanıyacak. Nesne kutuları yapmayı düşünüyorum. Mesela a harfi ile başlayan nesneleri onun içine koy. Bu a harfi gibi. Kutunun üzerinde sadece harfi görecekler ama yazmayacaklar." 
6 yaş (61- 72 ay) grubu öğretmenlerinde olduğu gibi 5 yaş (48- 60 ay) öğretmenleri de okuma yazmaya hazırlık etkinliklerini birden fazla çalışma ile gerçekleştirmektedir. Bu çalışmalara bakıldığında basitten karmaşığa doğru bir yol izlendiği belirtilmiştir. Bir öğretmen başlangıçta renklere, sonra şekillere sonra da sayılara yönelik etkinlikler yaptı̆̆ına ilişkin görüşleri aşağıdaki ifadelerde yer almaktadır.

"Kavram çalışmaları yaptırıyorum. Yıllık planda aldığımız kavramlar, sayılar, şekiller oluyor. Şekillerle başladık. Çünkü çocukların sadece üç tanesi önceden bu okula devam ediyordu. Bu yıl hepsi yeni başladılar. Mümkün olduğunca basitten aldım. Kavram bilgileri iyi olanlar vardı ama çok zayıf olanlarda vardı. İlk başta renklerle başladım, sonra şekille, sonra da sayılarla ilgili çalışmalar yapıyorum.. Sayılarla birlikte nokta birleştirme, çizgi çalışmaları da yapıyorum. Geometrik şekillerle ya da büyük resim çizdiriyoruz. Kalın mum boyalarla yapiliyor."

Okuma yazmaya hazırlık etkinliklerinde matematikle ilgili çalışmalar ve çizgi çalışmalarının yapıldığı ancak bunların daha çok düz çizgilerle yapıldığı, seslere ilişkin sistematik bir yol izlenmediği ancak hayvan seslerine yönelik bazı çalışmaların yapıldığı yani ses çalışmalarının dolaylı olduğu aşağıda bir öğretmen tarafından belirtilmiştir.

Test (kağıt) çalışmaları, kavramlar, matematik kavramları, eşleştirme, örüntü, farkllıkları bulma, hikaye oluşturma, boş bir kağıt verip bir hikaye anlatıp sonunda neler olabileceği ile ilgili resim çizmelerine yönelik çalışmalar yapıyorum. Nesnelerle toplama çıkarma yapıyoruz. 5 yaşa uygun olan, eğilmeyen kıvrlmayan çizgi çalışmaları yaptırıyorum. Çünkü elleri henüz eğik çizgiye göre hazır değil. Çabuk yoruluyorlar. Ama kurbă̆anın zıplaması gibi basit eğik çizgileri çiziyorlar. Seslerle ilgili özel çalışma yapmıyoruz. Ama hayvan sesleriyle ilgili çalışmalara yer veriyorum. Bu ses hangi hayvanin sesi ya da mesela eşek "ai" der gibi. Resimler gösteriyoruz. Elma erik armut. Hangisi e sesiyle başlar. Bu tür çalışmaları çok az yapıyoruz, sene sonunda veriyoruz. Seslerin verilişinde ilköğretimde bildiğim kadarıly sesli harflerle başlyyorlar. Daha doğrusu kelimelerin arasındaki ses benzerliklerini fark etmelerine yönelik çalışma yapıyoruz."

Okuma yazmaya hazırlıkta kullanılan materyaller: Özellikle 6 yaş (61- 72 ay) grubundaki öğretmenlerin okuma yazmaya hazırlık çalışmalarında kitaplardaki çalışma sayfalarını tercih ettiklerini belirttikleri görülmüştür. Bunun yanı sıra okuma yazmaya hazırlık çalışmalarında sınıftaki çeşitli nesnelerin (kavramlara yönelik çalışmalarda) materyal olarak kullanıldığı ifade edilmiştir. 
Bir öğretmen okuma yazmaya hazırlık çalışmaları için dergi, kitap gibi materyallerin kullandı̆̆ını "Çizgi çalı̧̧ma kitabı, dergilerin içinde şekil çalışmaları, kendi kitaplarm var, onları kullanıyorum. Kavramları veriyorum. Mesela büyük küçük onlarda olabiliyor" ifadeleri ile belirtmiştir.

Başka bir öğretmen ise okuma yazmaya hazırlık çalışmaları için yeterince kart vb. oyun materyalinin bulunmadığını şu cümlelerle ifade etmiştir:

"Kartlarla benzerini bulma gibi materyaller elimizde yok, eşleştirme, eksik tamamlama gibi materyaller yok. O tür çalışmalarda okuma yazmaya hazırlıkla ilgili kavram geliştirici çalışmalara yönelik materyal yok.

6 yaş (61-72 ay) grubu öğretmenlerinde olduğu gibi 5 yaş (48- 60 ay) grubu öğretmenleri de kağıt çalışmalarını okuma yazmaya hazırlık etkinliklerinde materyal kullandıklarını belirtilmişlerdir. Bunun yanı sıra renk, sayı gibi bazı kavramların öğretilmesinde sınıfta bulunan materyallerin kullanıldığı bir öğretmen tarafından şöyle ifade edilmiştir:

“Çocukların kalemle yapabilecekleri kă̆ıt çalışmaları veriyoruz.. Renk kavraminda hangi rengi veriyorsam oyuncaklardan o rengi bulmalarm istiyorum, sayılarla ilgili oyuncaklardan şu kadar alın gibi etkinlikler yapıyorum. . Mesela legoları koyuyoruz ortaya üç tane kırmızı renkte lego getir diyoruz. Sonra da legoları sayıyoruz. Renkler ve sayılarla ilgili kă̆ıt üzerinde çalışmalar yapıyoruz."

Bir başka öğretmen ise sınıf içinde bulunan farklı materyallerin okuma yazmaya hazırlıkta kullanıldığını "Ne bulursak onu kullanıyoruz. Çalışma kağıtları, kalemler, oyuncaklar, minderler, atık materyaller, kağıtların sesi, cam sesi, metal sesi, ritim aletleri, farkl enstrüman resimleri de kullanıyoruz" diyerek ifade etmiştir.

Okul öncesi dönemdeki çocuklar ilköğretime başlamadan önce sahip olması gereken beceriler: İlköğretime başlamadan önce çocuğun kazanması gereken beceriler hem 5 (48- 60 ay) hem de 6 (61- 72ay) yaş grubu öğretmenleri tarafından aşağıda belirtilen başlıklarda özetlenmiştir:

1. Kalem tutma, çizgi çizme

2. Kas becerilerini ve el göz koordinasyonun gelişmesi

3. Kavramların öğrenilmesi

İlköğretime hazırlıkta kalem tutma ve kas becerilerinin gelişiminin önemli olduğunu bir öğretmen aşağıdaki cümlelerle belirtmiştir: 
“Öncelikle el kaslarını geliştirici, güçlendirici çalışmaların yapılmasından tarafım. Çünkü çocuklar bu konuda çok sıkıntı çekiyorlar. Kolum yoruldu, bileğim ağrıyor gibi şikâyetlerde bulunuyorlar. O konuda çocukların hazır ilköğretime gitmesini en azından kalem tutmanın, makasla bir şeyler kesmenin, dil gelişimi sağlanmasının önemli olduğunu düşünüyorum. Veliler bilinçliler önceden çalışmalar yapıyorlar. Ama daha önce geldiğim okulda hiç eline kalem almamış kitapla tanışmamış çocuklar vardı. Onları düşünün hiç bir şey almamış eline direkt gelmiş birinci sınıfa oturmuş, çocuktan ne bekleyebilirsin? Herkes yazarken o çocuk yeni her şeyi başarma çabasında yani o açıdan çok önemli olduğunu

düşünüyorum. En azından burada çocuk her şeyi görüyor uygulayarak öğreniyor. İleriki yıllarda okul aşamasına bunu ilkokul öğretmenleri söylüyor, özellikle anasınıfından gelenler hemen belli oluyor diyorlar. Çocuklar gelişimlerini tamamlamıs olarak gidiyorlar."

Başka bir öğretmen ise kalem tutma, kas gelişimine ek olarak kavramların da ilköğretime hazırlıkta önemli olduğunu "Günlük kullanabilecek kavramları, kelimeler bilmeli, yazarken kas becerileri gelişmeli, doğru kalem tutmayı en azından düz ve eğri çizgi çizmeyi biliyor olmalı" ifadesi ile belirtmiştir.

5 yaş (48- 60 ay) grubu öğretmenleri de 6 yaş (61- 72 ay) grubundaki öğretmenleri gibi, kalem kullanma, el göz koordinasyonu ve kavram çalışmalarının ilköğretime hazırlıkta önemli olduğunu belirtmişlerdir.

Öğretmenlerden biri ilköğretime hazırlıkta önemli gördüğü becerileri aşağıdaki ifadelerle açıklamıştır:

"Kalemle düz çizgileri, nokta birleştirme ya da çizgi çalı̧̧malarında mümkün olduğunca en iyi seviyede olması gerekiyor. Noktalarm üzerinden gitmesi gerekiyor. El göz koordinasyonu açısından. Kavramlar da standart sorduğumuz sorulardan daha farklı sorduğumuzda da aynı yanıtı verebiliyorsa o yeterlidir bence. Mesela iki tane elma var hangisi büyük hangisi küçük. Üçgen mesela üçgenin çatısı neye benziyor? Hangi şekle benziyor. Başka ortamlarla ilişkilendirebilmeli mesela şu diz üstü bilgisayara baktığında direk şeklini görebilmeli. Çevresiyle ilişkilendirebilmeli"

Bir öğretmen ise bu ilköğretime hazırlıkta kavram çalışmalarını, yazı yönünü ve kalem tutmanın önemli olduğunu "Kavram öğretiminin önemli olduğunu düşünüyorum. Yazının yazılış yönünü öğrenmeli. Kalem tutmayı da bilmeli. 5 yaşta artık eskisi gibi değil, çok ilerliyorlar" diyerek ifade etmiştir.

Araştırma kapsamında görüşme yapılan öğretmenlerin ilköğretime hazırlıkta özellikle kalem tutma ve çeşitli özellikteki çizgileri 
çizme becerisinin, el- göz koordinasyonun ve kavramların kazanılmasını önemli olduğunu belirttikleri görülmüştür. Araştırma bulgularına göre öğretmenlerin okul öncesi dönemdeki çocukların ilköğretime başlamadan önce kazanmaları gereken beceriler arasında yazı farkındalığının ve ses farkındalığını belirtmedikleri görülmüştür.

\section{Tartışma}

Görüşme yapılan öğretmenlerin hemen hemen her gün okuma yazmaya hazırlık çalışması yaptırdıkları tespit edilmiştir. Ancak araştırma sonucunda ortaya çıan görüşlerin bazılarında okuma yazma hazırlık çalışmalarının daha çok altı yaştan itibaren yapılması gerektiğinin belirtildiği görülmektedir. Okuma yazma gelişimi çocuklar okula başlamadan önce hatta yaşamın ilk yıllarından itibaren başlayan ve yaşam boyu devam eden bir süreçtir (Morrow, 2005). Çocuklar doğdukları andan itibaren yazı dolu bir çevrede bulunmakta ve okuma ve yazma ile ilgili ilk bilgilerini bu çevre içinde öğrenmeye başlamaktadırlar (Riley ve Reedy, 2003). Okul öncesi dönemdeki çocukların gelişimsel olarak okuma ve yazma ile ilgili kazandıkları beceriler, onların ilköğretimdeki okuma ve yazma öğreniminde temel beceriler olarak görülmektedir. $\mathrm{Bu}$ becerilere sahip olmayan çocuklar ilk okuma ve yazma öğrenimine başladıklarında zorlanabilirler (Justice ve Ezell, 2001). Bu nedenle sadece 61- 72 aylik dönemde değil, okul öncesi eğitimin bütün yaş gruplarında okuma yazmaya hazırlık çalışmalarına önem verilmesi gerekmektedir.

Araştırma sonucunda okuma yazmaya hazırlık çalışmaları kapsamında kavram (sayı, renk, geometrik şekil vb.), çizgi ve ses çalışmalarının yapıldığı belirtilmiştir. Genellikle öğretmenlerin fen ve matematik etkinlikleri kapsamında yer alan sayılar, geometrik şekiller gibi matematik kavramlarına okuma yazmaya hazırlık etkinlikleri içinde yer verdikleri görülmektedir. Benzer şekilde Tuğluk ve diğerleri (2008) tarafından yapılan araştırmada, okul öncesi öğretmenlerinin okuma yazmaya hazırlık çalışmaları kapsamında en çok sayı, renk, şekil gibi kavramlarla ilgili çalışmalara yer verdiklerini ancak ses çalışmalarına az yer verdikleri bulunmuştur. Oysaki sayılar, sayısal işlemler, geometrik kavramlar okuma yazmaya hazırlık etkinlikleri kapsamında değil, matematik etkinlikleri kapsamında ele alınmalıdır (Buldu, 2010; Kandır ve Orçan, 2010; Starkey ve diğerleri, 2004; Şimşek, 2011). Bu açıdan değerlendirildiğinde MEB (2006) 36-72 Aylık Çocuklar İçin Okul Öncesi Eğitim Programı'nda yer alan fen ve matematik etkinlikleri kapsamına sadece fen etkinliklerinin değil, matematik etkinliklerinin de yerleştirilmesi gerekmektedir. Çünkü böyle bir ayrımın net bir şekilde yapılmaması 
öğretmenlerin uygulamalarında karışıklığa neden olduğu düşünülmektedir. Okuma yazmaya hazırlık çalı̧̧malarında yer alan çalışmalar ise okuma yazmayla ilgili kavramları, ses farkındalığı, yazı farkındalığı, yazma, sözel dil becerilerini içermelidir. 2004 Türkçe (1-5. Sınıflar) Öğretim Programında Türkçe öğretiminde, sadece dinleme, konuşma, okuma, yazma, görsel okuma ve görsel sunu gibi dil becerilerinin geliştirilmesi değil, aynı zamanda düşünme, anlama, sıralama, sınıflama, sorgulama, ilişki kurma, eleştirme, analiz-sentez yapma ve değerlendirme gibi zihinsel becerilerinin geliştirilmesi de ele alınmıştır. Türkçe öğretiminde dil becerileriyle birlikte zihinsel becerileri geliştirme de ön plana çıarılmıştır (Güneş, 2009). Bu bağlamda okul öncesi eğitim programında yer alan okuma yazmaya hazırlık çalışmalarının, ilköğretim Türkçe programı ile paralellik göstermesi ilköğretime hazırlık için de önemli görülmektedir.

Okul öncesi eğitimde okuma yazma hazırlık çalışmaları kapsamında çocukların desteklenmesi gereken alanlardan biri yazmaya hazırlık çalışmalarıdır. Araştırma kapsamında görüşleri alınan öğretmenler, okuma yazmaya hazırlık çalışmaları içinde çizgi çalışmaları (noktaları birleştirme, kesik çizgileri birleştirme) yaptırdıklarını ifade etmişlerdir. Pierce (2003) günlük yazma etkinliklerinin okuma gelişimine etkisine yönelik yaptığı araştırmasında, çocukların yazma çalışmaları ile desteklenmeleriyle birinci sınıfa başladıklarında okumayı daha kolay öğrendikleri sonucuna ulaşmıştır. Bu nedenle öğretmenlerin yazmaya hazırlık çalışmalarına yer vermelerinin gerekli olduğu düşünülmektedir. Güneş (2007) yazmanin fiziksel, zihinsel, gelişimsel, etkileşimsel süreçlerden meydana geldiğini belirtmektedir. Yazmanın fiziksel süreci içinde, kalem tutma, çizgi çizme, el hareketleri, soldan sağa yazma gibi beceriler yer almaktadır. Bu süreçle bağlantılı olarak okul öncesi dönemdeki çocukların yazmaya fiziksel olarak hazır olabilmeleri için sekiz beceriden söz edilmektedir; bunlar küçük kas becerilerinin gelişmesi, el- göz koordinasyonu, yazma için gerekli olan araç gereçlerin tutulması, temel çizgilerin çizilmesi, yazı dilinin yönünün fark edilmesi, alfabedeki harflerin yönünün anlaşılması olarak sıralanabilir (Eliason ve Jenkins, 2003; Marr ve diğerleri, 2001). Araştırma kapsamında görüşleri alınan öğretmenlerin çocukları yazmanın fiziksel sürecini dikkate alarak destekledikleri görülmektedir. Okul öncesi dönemdeki çocukların çizgi çalışmaları yapmaları önemlidir. Çizgisel örnek alıştırmalar, öğretmen tarafından ilköğretimdeki yazı öğretimi ilkelerine uygun olarak önceden hazırlanmalıdır. Seçilen çizgi alıştırmaları harflerin anatomik yapılarına uygun olmalıdır. Başlangıçta harf yapılarını oluşturan çizgileri ve diziliş yönlerinin öğretimi daha karışık harflerin kavranmasında büyük katkılar 
sağlamaktadır (Duran, 2009). Duran (2009) tarafından yapılan araştırmada okul öncesi dönemdeki çocukların yazmaya hazırlık becerilerini desteklemek amacıyla hazırlanmış olan eğitim programının çocukların yazma becerilerini geliştirdiği sonucu bulunmuştur. Araştırmada deney gurubundaki çocukların, kontrol grubundaki çocuklara göre daha hızlı yazı yazdıkları, imla kurallarını uygulama konusunda daha başarılı oldukları ve yazılarının okunaklı olduğu görülmüştür. $\mathrm{Bu}$ becerileri geliştirme konusunda kontrol grubu öğrencilerin sorunlar yaşandığı gözlenmiştir. Benzer şekilde Şimşek (2011) tarafından yapılan araştırmada okul öncesi dönemdeki çocuklara yazı farkındalığı ve yazmaya hazırlık becerilerini desteklemeye yönelik eğitim programı uygulandığında çocukların yazmaya hazırlık becerilerinde program uygulanmayan çocuklara göre artış olduğu saptanmıştır. Bu doğrultuda okul öncesi öğretmenlerinin çocukların yazmaya hazırlık çalışmaları yapmalarının önemli olduğu görülmektedir. Ancak araştırma kapsamında görüşme yapılan öğretmenlerin hiç biri okuma yazmaya hazırlıkta yazı farkındalığının kazanılmasından söz etmemiştir. Okul öncesi dönemdeki çocukların yazıyı okumaları beklenmese de yazı kavramlarını kazanmaları ve yazının farkında olmaları gerekmektedir (Ezell ve Justice, 2005). Okul öncesi dönemdeki çocuklarla yapılan araştırmalar, çocukların ileriki dönemlerdeki okuma becerilerini tahmin etmede en güçlü becerilerden birinin yazı farkındalığı olduğunu tespit etmişlerdir (Farver, Nakamoto ve Lonigan, 2007; Kelman, 2006).

Okuma yazmaya hazırlık çalışmaları içerisinde 6 yaş (60- 72 ay) öğretmenleri özellikle sesli harfleri ses çalışmaları ile verdiklerini ifade etmişlerdir. 6 yaş (60- 72 ay) öğretmenlerinden birisi ise çocukların sesle birlikte harfleri de tanımasına yönelik etkinlik yapmak istediğini ancak bitişik eğik yazı (el yazısı) ile dik temel harfler (düz yazı) arasında farklılık olduğu, bu nedenle dik temel harflerle yapacağ öğrenmeleri açısından sıkıntı olabileceğini belirtmiştir. 5 yaş (48- 60 ay) öğretmenlerinin ise ses farkındalığına fazla değinmedikleri görülmüştür. Yapılan görüşmeler sonucunda okul öncesi öğretmenlerinin harf ve ses kavramlarını birbirinin yerine kullandığı görülmektedir. Bu durum iki kavram arasındaki farkın anlaşılmadığını okul öncesi dönemde ses çalışmalarının harf öğretimi ile karıştırıldığını düşündürmektedir.

Araştırmada okul öncesi öğretmenlerinin ses çalışmaları hakkındaki görüşlerinin sınırlı olduğu görülmektedir. Öğretmenler ilköğretime hazırlıkta, kavramların ve yazmaya hazırlık becerilerinin (çizgi becerileri) kazanılmasının önemli olduğunu ifade etmişler, fakat ses farkındalığının 
önemine ilişkin görüş bildirmemişlerdir. Parlakyıldız ve Yıldızbaş (2004) yaptıkları araştırmada, okuma yazma hazırlık çalışmalarının kavramları hafızada tutma, renk, sayı vb. ayırt etme, şekil ve diğer kavramları kazandırmanın çocukların ilköğretime hazırlanmaları açısından önemli olduğunu belirttiklerini bulmuşlardır. Yapılan diğer bazı araştırmalarda benzer sonuçları göstermektedir (Tuğluk ve diğerleri, 2008; Patterson, 2002). Ses farkındalığı okuma başarısı için oldukça önemli bir beceridir. Okul öncesi dönemde çocukların ilköğretimde gösterecekleri okuma becerilerini tahmin etmede en belirleyici becerilerden biri olarak kabul edilmektedir. Yapılan araştırmalar okul öncesi dönemdeki çocukların ses farkındalığının okul öncesi dönemdeki diğer okuma-yazma becerileri ile ilişkili olduğunu ve ileriki yaşlarda okuma-yazma becerilerinin kazanılmasında çok etkili olduğunu göstermektedir (Anthony ve diğerleri, 2006; Anthony ve diğerleri, 2007; Batson-Magnuson, 2009; Burgess, 2002; Lonigan, Burgess ve Anthony, 2000). 2004 Türkçe (1-5. Sinıflar) Öğretim Programında, Türkçe öğretiminde ses temelli cümle yöntemine geçilmiş olması okul öncesi dönemde ses çalışmalarının yapılmasının önemini daha da arttırmaktadır.

Araştırma kapsamında görüşleri alınan öğretmenler okuma yazmaya hazırlık çalışmalarında materyal olarak genellikle kitapları ve çalışma sayfalarını tercih ettiklerini belirtmişlerdir. Benzer şekilde Arnas ve diğerleri (2003) araştırmalarında öğretmenlerin okuma yazmaya hazırlık çalışmaları için daha çok kitap ve defter çalışmalarını tercih ettiklerini ve büyük çoğunluğunun çizgi çalışmalarını yaptıkları saptamışlardır. Oysa öğretmenler okuma yazmaya hazırlık çalışmaları kapsamında pek çok materyali kendi geliştirerek kullanabilirler.

Okul öncesi eğitim programında müzik etkinlikleri kapsamında yapılan ses çalışmaları, ritim çalışmaları ses farkındalığını, sanat etkinlikleri sırasında yapılan çalışmalar küçük kas becerilerini, el - göz koordinasyonunu, kitap okuma etkinlikleri, tekerlemeler, şiirler, bilmeceler çocukların sözel dil becerilerini, yazı farkındalığını, kelime - kavram bilgisini ve ses farkındalığını arttırmaktadır. Genel olarak değerlendirildiğinde okul öncesi eğitim programı içinde yer alan bütün etkilikler çocukların okuma yazma gelişimini desteklemektedir. $\mathrm{Bu}$ nedenle okul öncesi eğitim programında yer alan etkinliklerin bütünleştirilmesi önem kazanmaktadır (Albayrak, 2000; Bay, 2008; Honing ve Shin, 2001; Kandır ve diğerleri, 2010; Şimşek ve Alisinanoğlu, 2009).

\section{Sonuç ve Öneriler}

Araştırmada, görüşme yapılan öğretmenler okuma yazmaya hazırlık çalışmaları kapsamında kavram, ses ve çizgi çalışmalarına yer 
verdiklerini belirtmişlerdir. İlköğretime hazırlıkta, kalem tutma, çizgi çizme, kas becerilerinin ve el göz koordinasyonun gelişmesi ve kavramların öğrenilmesinin önemli olduğu vurgulanmıştır. Öğretmenlerin ses çalışmalarıyla ilgili sınırlı bilgiye sahip oldukları ve yazı farkındalığı ile ilgili görüş bildirmedikleri görülmüştür. $\mathrm{Bu}$ durum öğretmenlerin yazı farkındalığı ile ilgili uygulama yapmadıkları ve bilgi sahibi olmadıkları şeklinde yorumlanabilir. Öğretmenlerin okuma yazmaya hazırlık çalışmalarında genellikle kitaplardan, çalışma sayfalarından yararlandıkları ve çevredeki nesneleri kullandıkları saptanmıştır. Öğretmenler çeşitli materyalleri geliştirerek oyunlar aracılı̆̆ıyla çocukların okuma yazmaya hazırlık becerilerini destekleyebilirler, ancak görüşme sonucunda bu tür bir bilgiye ulaşılamamıştır. Araştırma sonucunda elde edilen bilgilere dayalı olarak, okul öncesi öğretmenlerinin okuma yazmaya hazırlık çalışmalarında desteklenmesi gerektiği söylenebilir. Yapılan araştırmalar okul öncesi öğretmenlerinin yazı farkındalığı, yazmaya hazırlı gibi okuma yazmaya hazırlık çalışmaları konusunda hizmet içi eğitime gereksinimleri olduğunu göstermektedir (Breit - Smith ve diğerleri, 2009; Fogo, 2008; Huls, 2002; Mol ve diğerleri, 2009; Lynch, 2009). Bu araştırmada da okul öncesi öğretmenlerinin uygulamalarda sorunlar yaşadığı tespit edilmiştir, bu nedenle okuma yazmaya hazırlık çalışmaları konusunda hizmet içi eğitim ile desteklenmesi önerilmektedir.

2006 MEB 36-72 Aylık Çocuklar için Okul Öncesi Ĕ̆itim Programı'nda yer alan okuma yazma hazırlık çalışmalarının, 2004 Türkçe (1-5. Sinıflar) Öğretim Programı'nda yer alan okuma ve yazma alanları ile paralellik gösterecek şekilde düzenlemesi önerilmektedir.

Araştırma Ankara ilinde belirlenen anasınıfları ve anaokullarında yapılmıştır ve nitel araştırmaların bir sınırlılığı olarak genellenememektedir. $\mathrm{Bu}$ nedenle araştırmanın bulguları doğrultusunda yapılacak diğer araştırmalar da daha geniş örneklem ile farklı okullarda nicel ve nitel verilerin birlikte kullanıldığı araştırmaların uygulanması önerilmektedir.

\section{Kaynaklar}

Albayrak, H. (2000). Okuma yazma hazırlık çalışmaları. Selçuk Üniversitesi Anaokulu Anasınıfı Öğretmeni El Kitabı. İstanbul: Turan Ofset.

Anthony, J. L., Williams, J. M., McDonald, R., Corbitt-Shindler, D., Carlson, C. D., and Francis, D. (2006). Phonological processing and 
emergentliteracy in spanish- speaking preschool children. Annals of Dyslexia, 56 (2), 239- 270.

Anthony, J. L. ,Williams, J. M., McDonald, R., and Francis, D. J. (2007). Phonological processing and emergent literacy in younger and older preschool children. Ann. of Dyslexia, 57, 113-137.

Arnas, A., Erden, Ş., Aslan, D., Cömertpay, B. (2003). Okul öncesi öğretmenlerin günlük programda yer verdikleri etkinlikler ve bu etkinliklerde kullandıkları yöntemler. G., Haktanır (Ed. ) OMEP Dünya Konsey Toplantısı ve Konferansı Bildiri Kitabı (ss. 435450) İstanbul: Ya-pa.

Batson-Magnuson, L. (2009). Phonological and non-phonological languageskills as predictors of early reading performance. (Doctoral dissertation,, University of Medicine and Dentistry of New Jersey, 2009). ProQuest Digital Dissertations, 3401054.

Bay, N. D. (2008). Ana sınıfı öğretmenlerinin okuma yazmaya hazırlık çalışmalarına ilişkin yeterlilik algılarının belirlenmesi. (Yayınlanmamış Yüksek Lisans Tezi, Gazi Üniversitesi)

Breit-Smith, A., Justice, L..M., Mcginty, A.S., and Kaderavek J. (2009). How often and how much? Intensity of print referencing intervention. Topics in Language Disorders, 4, 360-369.

Bloch, C. (2000). Literacy in the early years: teaching and learning in multilingual early childhood classrooms.

<www://web.uct.ac.za/depts/praesa/OccPab1.pdf > (Erişim tarihi: 12.06.2006).

Bodrova, E. and Leong, D. (1996). Tools of the mind the Vygotskian approach to early childhood education. (1th Edition). America: Pretice Hall.

Breit-Smith, A., Justice, L..M., Mcginty, A.S., and Kaderavek J. (2009). How often and how much? Intensity of print referencing intervention. Topics in Language Disorders, 4, 360-369.

Brennan, S. A. (2008). Differentiated instruction and literacy skill development in the preschool classroom.(Doctoral dissertation, The University of Iowa, 2008). ProQuest Digital Dissertations, 3342239. 
Buldu, M. (2010). Okul öncesi dönemde matematiksel kavram gelişimi. Editör: Berrin Akman. Okul öncesinde matematik eğitimi.(ss. 2849). Ankara: Pegem Akademi.

Burgess S. R. (2002). The influence of speech perception, oral language ability, the home literacy environment and pre- reading knowledge on the growth of phonological sensitivity: a one-year longitudinal investigation. Reading and Writing:AnInterdisciplinary Journal, 15, 709-737.

Cabell, S. Q. Justice, L. M. , Konold, T. R., and McGinty, A. S. (2011). Profiles of emergent literacy skills among preschool children who are at risk for academic difficulties. Early Childhood Research Quarterly, 26, 114.

Clark, P. and Kragler, S. (2005).The impact of including writing materials in early childhood classrooms on the early literacy development of children from low-income families. Early Child Development and Care. 175, 4, 285-301

Deretarla Gül, E., ve Bal, S. (2006). Anasınıfı öğretmenlerinin okuma yazmaya hazırlık çalışmalarına ilişkin akış açıları, sınıf içi kullanılan materyal ve etkinlikler ile çocukların okuma yazmaya ilgilerinin incelenmesi. Çocuk Gelişimi ve Eğitim Dergisi, 12, 33- 51.

Dodge, D.T., Colker, L.J., and Horaman, C. (2002). The creative curricullum for preschool. Washington: Teaching Strategies.

Duran, E. (2009). Bitişik eğik yazı öğretimi çalışmalarının çeşitli değişkenler açısından incelenmesi. (Yayımlanmamış Doktora Tezi, Gazi Üniversitesi).

Eliason, C., and Jenkins, L. (2003). A practical guide to early childhood curriculum. (7th edition) . New Jersey: Merril Prentice Hall.

Ezell, H. K., and Justice, L. M., (2005). Shared story book building young children's language and emergent literacy skill. Maryland: Paul H. Publishing Co. Inc.

Farver, J. M., Nakamoto J., and Lonigan C. J. (2007). Assessing preschoolers' emergent literacy skills in english and spanish with the get ready to read! screening tool. Annals of Dyslexia, 57(2), 161-178.

Fogo, L. J. (2008). Writing in preschool (Doctoral dissertation, Purdue University, 2008) ProQuest Digital Dissertations, 3330282. 
Güleç, G. (2008). Okul Öncesi öğretmenlerinin okuma yazmaya hazırlık çalışmaları ile ilgili görüş ve uygulamaları. (Yayınlanmamış Yüksek Lisans Tezi, Pamukkale Üniversitesi).

Güneş, F. (2007). Ses temelli cümle yöntemi ve zihinsel yapılandırma. (1. baskı). Ankara: Nobel Yayıncilık.

Güneş, F.(2009). Türkçe öğretiminde günümüz gelişmeler ve yapılandırıcı yaklaşım. Mustafa Kemal Üniversitesi Sosyal Bilimler Enstitüsü Dergisi, 6 (1) 1- 21.

Honing, G, A. S., Shin, M. (2001). Reading Aloud With Infants and Toodlers and in Child Care Settings: An Obervational Study. Early Childhood Education Journal., 28 (3), 193-197.

Huls, T. A. (2002). Exploring language and literacy development of head start preschoolers. Doctoral Dissertation. Universty of Sourth Florida. Dissertation Abstracts International, 63/11, 3849.

Jackman, H.,L. (2005). Early education curriculum. A child's connection to the world.(3th Edition). United States of America: Thomson Delmar Learning.Justice L. M. and Ezell, K. E. (2001). Word and print awarenss in 4- year- old children. Child Language Teaching and Therapy, 13, 207- 225.

Justice L. M., Chow, S.M. , Capellini C., Flanigan. K., and Colton S. (2003). Emergent literacy intervention for vulnerable preschoolers: relative effects of two approaches. American Journal of Speech-Language Pathology, 12, $320-332$.

Kandır, A. ve Orçan, M. (2010). Okul öncesi dönemdeki matematik eğitimi. Ankara: Morpa.

Kandır, A., Tezel Şahin, F., Dilmaç, B., Yazıcı, E. (2010). İlköğretime geçiş sürecinde okuma yazmaya hazırlık çalışmaları. 9. Sınıf Öğretmenliği Eğitimi Sempozyumu (20-22 Mayıs 2010), Elazığ, s. 207-210.

Kelman, M. E. (2006). An investigation of preschool children's primary literacy skills, (Doctoral dissertation, University of Wichita State, 2006). ProQuest Digital Dissertations, 3261874.

Kılıçarslan, F. (1997). Farklı sosyo-ekonomik düzeydeki anaokulu çocuklarının okumaya hazır olma durumu. Yayımlanmamış Yüksek Lisans Tezi. Hacettepe Üniversitesi, Sosyal Bilimler Enstitüsü: Ankara. 
Lonigan, C. J.,. Burgess, S. R, and Anthony, J. L. (2000). Development of emergent literacy and early reading skills in preschool children: evidence from a latent-variable longitudinal study. Developmental Psychology, 36(5), 596- 613.

Lynch, J. (2009). Preschool teachers' beliefs about children's print literacy development. Early Years, 29 (2), 191- 203.

Marr, D., Windsor, M. M., and Cermak, S. (2001). Handwriting readiness: locatives and visuomotor skills in the kindergarten year. Early Childhood Research Practice,3 (1), 1- 17.

Miller, R. (1996). The developmentally appropriate inclusive classroom in early classroom in early education. New York: Delmar Publisher Inc.

Mol, S. E., Bus, A. G., and Jong M. T. (2009). Interactive book reading in early education: a tool to stimulate print knowledge as well as oral language. Review of Educational Research, 79( 2), 979-1007.

Morrison, G. (1998). Early childhood education today. (7th Edition). Columbus, Texas: Merril an Impirint of Prentice Hall.

Morrow, M.L. (2005). Literacy development in the early years. (5 th Edition). America: Pearson Copyright.

Murphy, M M. (2007). Enhancing print knowledge, phonological awareness, and oral language skills with at-risk preschool children in head start classrooms (Doctoral dissertation, University of Nebraska, 2007). ProQuest Digital Dissertations, 3271904.

Parlakyıldız, B. , Yıldızbaş, F. (2008). Okulöncesi eğitimde öğretmenlerin okuma yazmaya hazırlık çalışmalarına yönelik uygulamaların değerlendirilmesi. XIII. Ulusal Eğitim Bilimleri Kurultayı, 6-9 Temmuz 2004 İnönü Üniversitesi, Eğitim Fakültesi, Malatya.

Patterson, J. R (2002). Teacher beliefs and practices in preschool literacy instruction. (Doctoral dissertation University of Illinois at Chicago,2002). ProQuest Digital Dissertations, 3047874.

Pehlivan D. (2008). Okul öncesi eğitim alan ve almayan öğrencilerin ilkokuma yazmaya geçiş sürecinin, öğretmen ve öğrenci görüşleri doğrultusunda değerlendirilmesi. (Yayınlanmamış Yüksek Lisans Tezi, Çukurova Üniversitesi).

Phelps, S. (2003). Phonological awareness training in a preschool classroom of typically developing children. Unpublished master's thesis, East 
Tennessee State University, 2003). ProQuest Digital Dissertations, 1413452.

Pierce, B. L. (2003). The great debate continued: does daily writting in kindergarten lead to invented spelling and reading?. (Doctoral dissertation, The University of North Texas, 2003). ProQuest Digital Dissertations, 3425261

Pullen, P.C., and Justice L.M. (2003). Enhancing phonological awareness, print awareness, and oral language skills in preschool children. Intervention in School and Clinic, 39; 87- 98.

Riley, J. and Reedy, D. (2003). Communacation, language and literacy: learning through speaking and listening and writing. Jeni Riley (Eds.) Learning in the years a guide for teachers of children 3-7 (pp.61-95). Great Britain: Cromwell Press.

Seefeldt, C. (2005). How to work with standart in the early childhood classroom. New York: Teacher College Press.

Starkey, P., Klein A., Wakeley, A. (2004). Enhancing young children's mathematical knowledge through a pre- kindergarten mathematics intervention. Early Childhood Research Quarterly, 19, 99- 120 .

Story, N. I. (2008). Pre-kindergarten summer school: an intervention for kindergarten readiness. (Doctoral dissertation, University of Wyoming, Laramie, Wyoming, 2008). ProQuest Digital Dissertations, 3320743.

Sperling,R. (2003). Classroom learning behaviors and reading skill development. Early Childhood Education Journal, 31(2), 139-142.

Şimşek, Ö.(2011). Okul öncesi eğitim programında planlama ve etkinlikler. Editör: F. Alisinanoğlu. Okul öncesi eğitimde özel öğretim yöntemleri. Ankara: Pegem Akademi.

Şimşek, Ö. (2011) 60- 72 aylık çocukların yazı farkındalığı ve yazmaya hazırlık becerilerinin gelişiminde okuma yazmaya hazırlık programının etkisinin incelenmesi. (Yayımlanmamış Doktora Tezi, Gazi Üniversitesi).

Şimşek, Ö., ve Alisinanoğlu, F. (2009). Examination of the effect of mother Tongue Activities Program on the reading readiness level of 
preschool children. Procedia Social and Behavioral Sciences, 1, 521528.

Tuğluk İ. H., Kök, M., Koçyiğit, S., Kaya, H.İ., Gençdoğan, B. (2008). Okul öncesi öğretmenlerinin okuma- yazma etkinliklerini uygulamaya ilişkin görüşlerinin değerlendirilmesi. Kazım Karabekir Eğitim Fakültesi Dergisi,17;72-81.

Vukelich, C., Christie, J., and Enz, B. (2008). Helping young children learn language and literacy: birth through kindergarten. Boston: Pearson Education Press.

Milli Eğitim Bakanlığ (2005) İlköğretim Türkçe dersi öğretim programı ve kılavuzu. Ankara: Devlet Kitapları Basımevi.

Milli Eğitim Bakanlığı (2006) 36-72 aylık çocuklar için okul öncesi eğitim programı. Ankara: Milli Eğitim Bakanlığı.

Yaden, D., Tam A, Madrigal, P., Brassell D., Massa J.,Altaminaro L.S., and Armendariz J. (2000). Early literacy for iner-city children: the effects pf reading and writing intervention in English and Spanish during the preschool years. The Reading Teacher, 54 (2), 186- 189.

Yangın, B., (2006). Yöneticilerin ve Öğretmenlerin İlk Okuma-Yazmaya Hazırlığa Yönelik Bilgileri ve Görüşleri, Mehmet Akif Ersoy Üniversitesi Eğitim Fakültesi Dergisi, 7 (12); 161- 175.Yıldırım, A.; H.,

Şimşek. (2008). Sosyal Bilimlerde Nitel Araştırma Yöntemleri. Ankara: Seçkin Yayınları 